\title{
Usage of Promotional Activities in the Service Sector - A Case Study on Bank Services Sector in Shkodër, Albania
}

\author{
Arsida Shimaj \\ Director of High School "Hamdi Bushati", Shkodër/Albania \\ arsidashimaj@rocketmail.com
}

\section{Doi:10.5901/mjss.2015.v6n2s5p259}

\begin{abstract}
This theme is an attempt to investigate and analyze how the use of promorcionale activities can help the development of the banking sector. As an important element of the marketing mix, promotion plays a vital role in the marketing of any product and service. And service banking system has no exception because customers want to know about the services and facilities for making their special offered by banks. As a result the spread of information and persuasion on the benefits of the services offered by banks are very important to attract the market to them. By the use of various means of promotion, banks try to serve this purpose and to influence consumers attitudes and increase potential interest to obtain these services back to their banks and reduce the risk that accompanies the product/service purchases. Although promotion plays an important role in marketing the product to the banking sector, the level of the banking system in our country is not in the parameters set out objectives for economic development. The main purpose of this study is to analyze the current situation and future possibilities banking sector operating in Shkodra, Albania and highlights as promotional activities can play an important role in the development of the banking system of a country like Albania. In the end of paper, based on the findings, are some suggestions for measures to improve policy management promorcionaleof banking. This sistem is a combination of theoretical and empirical research.
\end{abstract}

Keywords: Menager perceptions, promotion, banking services, Shkodër/Albania

\section{Introduction}

World economy is becoming overpowered by the the industry of services. It consists of the economic sector with the fastest development in all the world, giving its contribution in the economic growth and in the growing of employment level. It is an industry that has its mayor support in an intensive use of manual work, in a close relationship with the client, and as a consequence of this it leads to the opening of new working places. In the conditions of a growing competition in the service sector and the usage of always more and morethese ch advanced technologies, this sector is being faced with new challenges. To deal with these challenges the service organizations are exploring the role of the marketing. The mixed marketing is a group of tools that are being used by the leaders of a service orghanisation to model its offer for the consumers. The decisions for one of the elements of a mixed marketing is taken only being refered to the other elements because only in this way it can secure a stable position of the product. Due to the nature of services, the mixed marketing is an expansion of the 4 traditional Points of the product ( product, price, promotion and place) in the 7 Points ( product, price, promotion, place, people, physical evidence, and processes) of the mixed marketing of the services. (Elmazi, 2003). The need for expansion of the traditional mix of the services is connected with a high direct contact between the servise orghanisation and the consumer, with a compliance in time between the production and the consume. In order to have the biggest share in the market, to answer the market requests, to maximixe their profits, it is necessary for the companies to make an effective advertising campaign. This happens because the potential market needs to be informed about the existence of the product, it nature, positive sides, otherwise it will not react. It can be considered a key feature the ability of the company to have a communication with its clients. Promotion has this role of communication. "The promotion can be defined as a summary of activities through which the enterprise aims to communicate with the market, in order to advertise its products and services" (Koja, V. 2006:13). To make these aims possible it uses a variety of promotional instruments. The mix promotion includes the combination of various instruments to satisfy the needs of the target market and to maximixe its profits. The components are: publicity, personal sales, promotion of sellings, direct marketing and public relationships (Koja, V. 2006). The companies have to know how to divide the general investments of the promotion into its components. Even inside inside the Same sector we can see big changes between the different unities and the special expenditures made for different instruments of the promotion. The companies are in constant search in order to obtain the most efficient combination of the promotional mix and they very often modify the importance 
of special elements every time their eficasity changes. Bancs are an important part of the market economy and the servise sector. They can play an unsostituible role as a way of investment and as a form of profit of a safe finantial service for people and orghanisations. A vital channel of communication between the banc- ist services and the clients is the marketing sector in these bancs. It has an important role during the campaign, the promoting and selling activities and in maintaining the image of the bank. To help them in selling the products, bancs use the different points of the mixed marketing, which helps them sent information, identify and differentiate the service, promote the usage of new services by new clients and suggest rebying it by the existing ones, expand the usage of service product, develop the brand preference and the fidelity toward it. While people and orghanisationswhon in their everyday lives have the tendency to take decision on how to use money, where to deposit it, to do transactions, to find funds for investments or to be orientated to promotional banc means to take information on the existence and nature of the service product, the positive sides they will receive from these services, information that they could use to take the decision of buying. The considerable consequences in the real sectors of the global economy caused by the the last finantial crisis that begun in the USA, the aggravating situation by means of this crisis, continuing with the aggravating situation in Greece, Italy, that are important commercial partners with our country and places where a lot of Albanian immigrants live, surely will have consequences in the Albanian economy and in the activity of the operating bancs. The Reports Publicated by the Banc of Albania tell that the degree of usage of the banking sy tem in not enogh to have a developed economy. Also, the use of cash in the economy is too high. All these phenomena feed the informality and reduce the efficiency of monetary politics. From the other side the world finatial crisis has lessened the trust of the clients in the banking system. Also in the conditions where the first money sending by the immigrants are seen as a targhet with enough profit for the activities of the bancs and when they constitute a big afflux of funds in the Albanian economy, IOM (International Migration Organization in Albania - 2014) notes that due to the finantial and economical global crisis, a great reduction is seen in the immigrant sendings during 2009 and in continuance, especially of those living in Greece and Italy and also a considerable part of these funds circulate outside legal channels and in most cases are used to provide basic needs for the families and relatives of the immigrants. So, these funds that enter from the immigrants do not play a considerable role in the economy and the finantial investment in Albania,partially because the Albanian financial institutions,si in fact these funds that enter from the immigrants do not play an important role In the economic expansion, and the finantial investment in Albania, partially because of the financial Albanian institution lack finantial products missing directed toward the first sending of the immigrants and the services that urge the services be done through legal channels of in a formal way. This is even more vital at the same time, according to the annual raports of 2013 të AAB (Association Albanian Banks- Shoqata Shqiptare e Bankave) deposits are the vital sourse of the funds, which has lessened during this economic year, being compared to 2011. With the scope of affronting these challenges, by which the banks play a vital role as a form of investment and as a form of profit, of a safe finantial service for people and, and also in the conditions of a growing competition, and because of the unconcrete nature of the bank products, and the need for information before buying the service for the potential clients, the promotional measures of the banking system, where banks play a vital role in the performance of this sector. Are the promotional activities those that constitute the targheted market of the banks. Through promotion the banks inform the client for the bank and its product services; to convince the clients that the offered product by this bank offers the best choice for the clients needs; it remembers the clients urging their attention to buy a special product, above all when it is offered in a specific time, so helping the banks to attract as more clients as possible and to also attract monetary values. Also the promotion of banking services shifting the attention on concrete elements to reduce the high risk level in the process of buying the ban service, making the clients look for the long effects, and to running toward higher interests. In the conditions of the finantial global crisis and of the possibility of its influence in our country, taking as a study case the banking system is a courage per se, for the efforts of taking measures to resist this crisis. The article tries to help in the development of the banking sector, with its intermediary role gives an important contribution in the national economy. Bancs can play an insostituible role as a way of investment and as a form of profit for people and orghanisations. It values and contributes in the close connection of bancs with the targeted market by means of usage of promotional activities. The findings of this article can be generalized in all the sector of second level bancs operating in Albania.

\section{Research's Hipothesis and Methodology}

Starting from the general case examines the scope of research to recognize the usage of promotional activities in the banking system, this case deals with hypothesis to be verified.

a. The undertaken promotional activities by the second level bancs operating in Albania were not enough.

This research deals with the second level bancs in the municipality of Shkodrës, bcts the because here exist a 
considerable number of residents that have immigrated ant that are a potential market to sell the service products the bancs offer. The research is initially based on secondary information and then in primary ones. But, by examining these secondary resourses exist many discussions on promotion usage in our banking system and less than that empirical research. So this case is based on primary datas gathered through survey using as a scientific instrument the questionnaires on the usage of promotional activities by the operating banking system in Shkodër. This questionnaire is half structured. In the questionnaire are used questions with alternatives, like Liquert scale, and free questions. The way of organizing the collection of datas is the compilement of the given questions. The population taken in this case are all bancs of secondary level operating in the municipality of Shkodrës. There are 12 operating banks in this municipality. The questions are designed and analysed to have a clear view on the aspects of promotional activities from the operating banking system in Shkodër. In the quantitative analysis are used means of descripting statistics, and the results are shown in tables and illustrated graphics.

\section{Analysis}

\subsection{The profile of the respondent population}

After 1997, from 3 that operated in Shkodër and 4 in all Albania till 1997 we have a sensitive growing number of private operating banks, 12 of second level and 16 in all the country. So most of the banks are new in their marketing activity, and as a consequence lack experience and capital directed toward necessary promotional activities to mark the banking services. iFrom all the operating banks in our country only 3 are with a totally local capital, wich operate in Shkodra too, and the others are with $75 \%$ foreign capital.

\subsection{Types of promotional activities undertaken from te bancs}

Almost all the banks use all the means of the mixed marketing to promote their activities. They make advertisements in newspapers, local magazines, electronic media. They also use printed materials in order to publicate the information to potential clients in order to attract the attention to the potential consumer. But they do not use any international medium to advertise their services in the neighbour countries where there might be immigrants interested to take advantage of the bank services. It is paid attention to the personnel of contact to have a good interaction and to keep good relationships with important clients and to motivate them to make use of the bank in order to satisty their needs. They also pay attention to the environment and the internal atmosphere as important and welcoming signs that could help in the apprecations of the bank services. They also pay attention to the techniques of sales promotion during the summer season to attract immigrant clients, or make use of preferential service packages for loyal banc clients. Some exploit different spaces for free publicity in the electronic media, tv shows, seminaries and conferences to be promoted, to create an image and grow trust in the potential market. To create good relationship with the public and the community, to reach new segments of market bancs sponsor different community activities.

\subsection{The period of undertaking promotional activities}

Most of the banks (83.4\%), make promotional activities during all year long, and the other remaining part, 2 bancs, (16.6\% of the total) do not. From the last two, only one promotes during the summer, which can be considered as a partial attempt to attract the potential market toward itself, a thing to be conidered the insufficient amount of funds.

\subsection{Methods of defining promotion budget}

Most of the bancs (33.3 \%) use the method according to the finantial possibilities in defining the promotion budget. This is the most common used method in defining the promotion budget, followed by three other bancs or $25 \%$ of the total, that use the method based on the objectives and duties, which is the rightest method to define the promotion budget. While the other bancs which constitute $16.7 \%$ of the total of the bancs use the method of fixed percentage on last year total sales and of arbitrary definition. Only one banc keeps the promotion bugdet same as that of the last year. From this view results that only $1 / 4$ of the bancs take into consideraton the objectives of marketing and those of the promotion and give funds to reach these objectives. 


\subsection{Perceptions on the sum spent in promotion}

When the banks were asked to tell about their perceptions if the spent sum for promotion, by means of their bank was enough or not, $50 \%$ of the banks expressed the opinon it was the maximum. While 2 other banks which constituted $16.7 \%$ of the total were neutral, which shows that the promotion budget was not enough or either it is possble the asked person has no clear idea to express his opinion on this case. While 4 of the bancs (33.3\% of them) think the budget in insufficient.In a situation like this it is explainable why from the publications results that some banks lack liquidity and need for depositing market and also for a growing trust toward the bancs in the conditions of a global finantial crisis, that is why they feel the need of promotional activities to attract potential market toward the bancs.

\subsection{Perceptions on the eficasity of the promotional activities undertaken by the bancs}

Nearly $50 \%$ of the banks accept the eficasity of the undertaken promotional activities. While the other half think that the undertaken promotional activities are not too efective, so give a neutral attitude, or can tell that the asked person has no idea on this issue. But according to a study IOM made most of the money sent by the immigrants constitute the biggest afflux of the funds in the albanian economy, circulate outside the official channels (nearly $77 \%$ of them). This shows that the promotonal activities are not as effective of enough. They do not use any intermediary outside Albania to attract the immigrants deposits and use legal ways to sent their money home.

\subsection{The attitude toward the role of promotional activities in the banking system}

Almost all the banks agree of completely agree that promotion plays an important role in the banking sector as a sector of service products. They seet it as an investment for a better banking performance.

\subsection{The attitude toward the need of growing promotional activities for the development of the operating banking system in Shkodër}

Most of the asked people (83.4\%) agree to undertake more promotional activities for a further development of the banking system, in order to exercise its successful function, that of finantial intermediate and that of economy supplier with payment instruments. Only $8.3 \%$ have a neutral attitude.

\subsection{General perceptions on promotional activities of the operating banking system in Shkodër}

The promotional efforts for goods and services are made to reach a better performance in order to accomplish the orghanisation goal. Exactly for this, this case tries to evaluate the undertaken promotional activities to have a clear meaning if they are performed in the right way or not. This evaluation will help to find if the promotion activities have played any role or not in the marketing of the products of the banking service, if the bancs spend enough funds in the promotion activities or not, are these activities effective or not.. The below table shows the general perceptions on promotional activities for the operating banking sector in Shkoder.

Table 3.1: Perceptons on the promotional activities of the operating banking sector in Shkodër

\begin{tabular}{|c|c|c|c|c|c|c|}
\hline \multirow[b]{2}{*}{ Factorët } & \multicolumn{5}{|c|}{ Frequency number } & \multirow[b]{2}{*}{ Average } \\
\hline & \begin{tabular}{|c|} 
Completely \\
agree $(\%)(5)$
\end{tabular} & $\begin{array}{l}\text { Agree } \\
(\%)(4)\end{array}$ & $\begin{array}{l}\text { Neutral (\%) } \\
\text { (3) }\end{array}$ & $\begin{array}{c}\text { Do not agree(\%) } \\
\text { (2) }\end{array}$ & $\begin{array}{l}\text { Do not agree at all } \\
(\%)(1)\end{array}$ & \\
\hline Promotional budget is enough & $3(25)$ & $3(25)$ & $2(16.7)$ & $4(33.3)$ & $0(0)$ & 3.41 \\
\hline $\begin{array}{l}\text { The undertaken activities of promotion are } \\
\text { effective }\end{array}$ & $2(16.7)$ & $4(33.3)$ & $6(50)$ & $0(0)$ & $0(0)$ & 3.66 \\
\hline Promotion has an important role on bancs & $8(66.7)$ & $4(33.3)$ & $0(0)$ & $0(0)$ & $0(0)$ & 4.66 \\
\hline There are needed more promotional activities & $6(50)$ & $4(33.3)$ & $1(8.3)$ & $1(8.3)$ & $0(0)$ & 4.25 \\
\hline
\end{tabular}

As it is seen by the above table, the highest reached average is 4.66 , far away from the medium average 3 and near the maximum 5 of acceptance which shows that the bancs believe that promotion plays an important role to attract potential clients toward themselves. While the average 4.25 , so above medium level 3 shows that most of the bancs $83.3 \%$ of 
them believe that they should undertake more promotional activities in defining the products of the banking services. The average of eficasity of the undertaken promotional activities, 3.66 , shows that $50 \%$ of the bancs accept the eficasity of the undertaken prompotional activities, while the other half keep a neutral attitude. This neutral attitude does not permit us to exactly judge if these activities were effective or not. While the lowest average 3.41 , very close to the minimal acceptance degree 4 and far away from the lowest degree of insuficiency 2 shows that (50\% of the bancs) se think tha the budget is enough and $33.3 \%$ think it is not, $16.7 \%$ take a neutral attitude. But again, the response level for enough funds from $50 \%$ of the bancs seem to be contradictory with the level of answering from $83.3 \%$ for the need from the bancs to do more promotional activities, which need more promotional budget. According to the suggestions for successful promoting activities fromthe bancs, all the asked people suggested more innovations in the products of banking service and in a marketing activity in order to avoid samepolitics between the bancs.

\section{Conclusions}

The conclusions given by the findings of the research as a reflecting of the main principles of research are: The industry of service constitutes the fastest growing service, which is giving its contribution in all the world, making possible the growing level of employment, the banking sector is an important part of the market economy and of the service sector. It can play an iunsubstituted role as a way of investment and as a form of profit of a safe finantial service for people and orghanisations; the activity of the finantial mediation in the economy of the banks in our country is being conditioned by the contraction of finantial resourses, the fluctuations of trust in the finantial institutions and the declining request for loans, our banking system continues to be mainly financed by the public deposits being mainly sconcerned in the activity of loan giving for the businesses; the first sending of the immigrants constitute the biggest afflux of funding in the albanian economy, leaving in second place the foreign investments and the exports; the degree of bank usage in our country it is not in the best parametres established to have a growing economy; banks lack finantial resourses designed and directed toward money sending by the immigrants or services tht promote to sent these sums of money in a formal way; banks do not give loans to small busnesses which constitute the main part in the Albanian economy; in the conditions of a finantial global crisis, of a more and more challenging market, of advanced technology usage, this sector is being directed toward the role of marketing; the promotion is an investment for a better banc performance; companies of banking service it is very important the development of effective promotional measure requests of the market, to attract potential clients, to maximixe their profits in a growing competition between themselves and the nature of the products they do not make use of; there is not empirical research connected to the usage of promotional activity in the operating banking system in our country;ere these are immigrants are located to promote their service offers and to facilitate transactions for these immigrants; the budget of promotion it is not enough, and it doe not take into consideration the marketing objectives and especially those of the promotion. Banks lack that kind of inovative technology which would make possible to promote qualitative and innovative acitvivities toward the potential market.

\section{Recomandations}

Based on research finding below are given some modest recomandations for managerial measirements in order to improve promotion in the operating banc sector in Albania:

Fluctuations of trust in the operating bancs in Albania is a result of the finantial global crisis and the distrust of the immigrants in these banks, and also the belief that the added transparence is translated in the integrity strengthening of the operating banc system in Albania together with the other reciprocal governmental orghans, it is required, the Bank of Albania to pay special attention to the education of the public . For this reason they must provide more information and publicate themin the reciprocal web-sites. Together with the banks of the second level operating in our country to hold more conferences and seminaries, to give programes more frequently that serve this mission in the electronic media. Internet can play an important role in the international exchange of information.

It is necessary to have a bigger promotional activity for promotional offers for the faithful clients. For example, they can redact new products, with preferential prices for those clients that take their salary in these banks, or that keep their accounts of businesses in these banks. This kind of strategy of ofering incentives to the existing consumers, can also play the role of advertising. They also have to take part in local fairs, national and international to promote new offers and to have potential markets. There must be done sponsoring of activities in the community, which help the image of the bank. There must be more innovations in the products of banking service and in the marketing activities especially in the promotional ones in order not to have the same service between banks.Different forms of promotion should be widespread through all the year and not only in the summer season. 
Banks should do a bigger promotion toward the specific markets like immigrants and smal markets. They shoul create finantial products directed in the money sending and services that promote bringings in formal ways. In this way, beside the usage of internet, thay should make publicity into our neighbour consolates and embassies, where most of these immigrants are gathered, or sponsor concerts of our artists in these countries, with the right to make publicity for these banks in the immigrant audience. Banks through promotional measures should encourage small businesses to take loans in these banks facilitating the proceduresa. Improvements should be done in the timing system of taking into consideration these applications and the answer giving, in the information required from the clients and the grounds of decision taking in order to publicate new offers which make easier the approach of small businesses in these banks. To specity the budget of promotion, banks should take into consideration the marketing objectives and especially those of the promotion to give funds for what is important to reach these objective.

\section{References}

AAB, (2013), Raport vjetor 2013. E vlefshme tek: http://www.aab.al/documents/rp/AABRaportVjetor2013.pdf

Banka Botërore, 2007, Mundësitë e Shqipërisë për financimin e sektorit të ndërmarrjeve. E vlefshme tek:http://siteresources.worldbank. org/INTALBANIA/Resources/Shqiperia_Aksesi_per_kredi_08.pdf

Belch, G. E. \& Belch, M. A., (2004), Advertasing and Promotion: An Integrated Marketing Communications Perspective. . McGrown Hills/Irwin, USA.

Dibra, M., (2006), "Si duhet ndërtuar mesazhi publicitar për të qenë i suksesshëm", Buletin Shkencor, Seria e shkencave shoqërore, USH "Luigj Gurakuqi", Viti XXXVI i botimit, Nr.56, Shkodër.

Elmazi, L. \& Kruja, D., (2008), Menaxhimi e Marketingu i shërbimeve, Camaj-Pipaj, Shkodër.

Elmazi, L., (2003), Strategjia Marketing: Strategjitë për rritjen e vlerës konsumatore dhe rentabilitetin, Sh.B.L.U, Tiranë.

Koja, V., (2006), Promocioni, albPAPER, Tiranë.

Ibrahimi, F., (2009), Kriza globale dhe ndikimi ne Shqiperi. E vlefshme tek : http://www.alblink.com/?fq=brenda\&m=shfaqart\&aid=2116

Ibrahimi, F., (2007), Gjendja e sistemit bankar dhe sfidat në të ardhmen.E vlefshme tek: http://www.bankofalbania.org/web/Gjendja_e_ sistemit_bankar_dhe_sfidat_ne_te_ardhmen_3963_1.php?kc=0,5,8,8,0

IOM Albania, (2014), Migration and Albania: Typology of Albanian migration. E vlefshme tek: http://www.albania.iom.int/index. php/en/albania

Philip J. Kitchen, (2004), Marketing Communications: Principles and Practice, Thomas Learning, 